\title{
Intermédialités
}

Histoire et théorie des arts, des lettres et des techniques

Intermediality

History and Theory of the Arts, Literature and Technologies

\section{Models for Public Space}

An interview with Adrian Blackwell

\section{Annie Gérin}

Numéro 14, automne 2009

bâtir

build

URI : https://id.erudit.org/iderudit/044415ar

DOI : https://doi.org/10.7202/044415ar

Aller au sommaire du numéro

Éditeur(s)

Revue Intermédialités (Presses de l’Université de Montréal)

ISSN

1705-8546 (imprimé)

1920-3136 (numérique)

Découvrir la revue

Citer ce document

Gérin, A. (2009). Models for Public Space: An interview with Adrian Blackwell. Intermédialités / Intermediality, (14), 173-179. https://doi.org/10.7202/044415ar 


\title{
Models for Public Space
}

\section{An interview with Adrian Blackwell}

\author{
AnNiE GÉrin
}

- he shrinking and impoverishment of public space is now a prominent theme in contemporary debates in art, architecture and urban planning. Since the 1960s, artists and architects, such as Melvin Charney, Gordon MattaClark, Dan Graham, Richard Greaves, Ant Farm and ParaSITE, have tackled this pressing issue by deconstructing, reframing and appropriating urban spaces and architecture, as well as by creating impermanent structures and models that serve the purpose of shifting habitual spatial practices. As a visual artist, architect and urban designer, Adrian Blackwell contributes to this tradition. His work focuses on the question of equality, access and democratic exchange in contemporary urban development and public space.

Since 1996 Blackwell has produced a series of art projects that aim at altering existing spaces to encourage common uses. For example, Public Water Closet (1998) and How to Open a Car Like a Book (1999) create private enclosures within the city. Recent works such as Light Net (2004), Car Pool (2006) and Model for a Public Space (2000, 2006 and 2008) produce temporary locations for collective action and public debate. Alongside these object-based propositions, Blackwell has also engaged in critical documentary work: Evicted May 1, 2000 (9 Hanna Avenue) (2001) uses pinhole photographs to record the transformative potential of artists' studio spaces; Detroit's Underdevelopment: Separation, Divesture, Erasure, Encampment (2005) draws on three maps to trace the social and political forces that shaped the development of Detroit in the second half of the $2 \mathrm{O}^{\text {th }}$ century; Factory = Territory (2005) documents the eastern edge of China's Pearl River Delta with drawings, maps and pinhole panoramas.

Adrian Blackwell is an assistant professor at the University of Toronto's John H. Daniels Faculty of Architecture, Landscape and Design, and a member of the Toronto School of Creativity and Inquiry. 
Annie Gérin: You were trained as an architect, you practised architecture and you teach architectural and urban design at the University of Toronto. Yet much of your current practice is directed towards art and collaborative actions.

Adrian Blackwell: I make art because it's a way to think creatively and produce, much more easily than architecture. Architecture came first and it's something I still really love, but it's so fraught with political and economic challenges. First, how do you get the money to make something? Then, how can you make something that is politically progressive or radical?

For years, before I started making art, I worked for an architect who designed extremely beautiful houses. He had a very modest and also very provocative, interesting way of making architecture. But at some point I realized this wasn't for me. I wanted to engage with public issues and work with people who can't afford to have an architect design their house. Art is much more direct in terms of aesthetic questions and its potential for realization. Art also allows more room for thought.

This interest in public issues and more immediate ways to produce seems contrary to the durability usually ascribed to architecture. In fact, your works, from pinhole photographs to ephemeral constructions, display a very fragile temporal quality.

I don't know if it's the only way I would like to do these things. But it has to do with an interest in relational ideas. I'm interested in the ways people use something more than the thing itself. So I think the fragility you refer to is another way of downplaying the artifact and the importance placed on it.

Do you consider that your work is connected to relational aesthetics?

The relational aesthetics thesis just makes sense to architects. Buildings are about social uses, right? At the same time, I am not satisfied with relational aesthetics in itself, because I believe in the necessity of making things. So my work is not exactly relational in the typical sense. Even if I tend to downplay the artifact, I'm still interested in fabrication and the artist's role as maker of useful things. 
This conception recalls that imagined by Constructivist artists in the early $20^{\text {th }}$ century. They asserted their role in shaping the everyday. Do you think artists still have the necessary agency to contribute usefully to society?

I certainly don't mean that the artist's role is to lead the community. But I think that art almost necessarily has to deal with and intervene in social and political contexts, it has to resonate with the world around it in a social and political way. As an artist I want to engage the city with my work. As far as I am concerned, one of the biggest problems facing the city is uneven development and the ways in which people are marginalized because of it.

But you certainly haven't chosen the path of community-based art.

This is where the question of autonomy comes in. I'm more interested in the constitutive tension between making work that is accessible and open to people, that people are curious about, and making work that has autonomy from the capitalist world that surrounds it - hopefully introducing some kind of otherness to it. This is a kind of resistant otherness. A lot of community art loses its constitutive tension. It doesn't always fully articulate its critique, because it is so involved in the immediacy of improving conditions. Community art can be problematic when artists are no longer pursuing their own process of art making. Art needs to have a certain distance.

It strikes me that your work is resistant to the shift towards what critics like Paul Ardenne term "micropolitics." It appears closer in spirit to what certain artists of the 1970 like Gordon Matta-Clark or Hans Haacke saw as a political project for art.

It's true. I mean those are certainly inspirations. Dan Graham's work and Robert Smithson's work are important references also. But a lot of the work I've been doing is much more directed in terms of the social and political implications. Certainly Dan Graham's work with corporate materials and surveillance targets questions of control and power in urban space. And Hans Haacke's work is a very extreme example of art that deals with political economy in a very straightforward way. I think art has to deal with the big political problems of post-Fordist capitalism and neoliberal governance.

Graham and Haacke's practices seem to have had a particular influence on your work with the October Group. 
Yes. The October Group project happened in the fall of 1996. It involved some very interesting characters: people like Kenneth Hayes, who has just recently published Milk and Melancholy, ${ }^{1}$ the filmmaker and sculptor Kika Thorne, architects Barry Isenor and Christie Pearson, theorist Cecilia Chen, photographers Derrick Wang and Daniel Diaz Arrasco, a group of artists and architects. It was an incredible moment, perhaps the most inspiring thing I've ever been a part of. It was a real collective action that was focused at a very particular moment - Metro Days of Action, a two-day general strike in Toronto - and a very particular site: Toronto's City Hall.

We built a 150 foot long inflatable tube that we illegally installed as a parasite over the air vent in front of Toronto's City Hall. It was set up on the eve of the first day of the strike at about ten o'clock. It was like a big noisy street toy or utopian architecture. With it we wanted to protest against the violent neoliberal policies of the Ontario government. It was about public housing primarily, and the way it was being destroyed in the 1990s.

But this was more than a comment on the destruction of public housing. Occupying a space such as City Hall directly confronts people. It makes them question their own agency. This is also what a work like Public Water Closet proposes.

At one level this was simply about putting a public washroom on the Queen/Spadina corner. There were no public washrooms to access in this area. In terms of rights to the city, it seemed to be a fundamental one. But then the structure was also about inverting mechanisms of surveillance. The tension in that piece probably resides in how you have power of surveillance at the moment when you are most vulnerable and have least desire to be seen. It was also very much framed by the legislation of the Safe Streets Act. It was put on Spadina because this is where there were the most squeegee kids cleaning car windows. There was a lot of controversy about businesses that wouldn't let them use the washrooms.

Do you know if people actually used it?

1. Kenneth Hayes, Milk and Melancholy, Toronto and Cambridge (Mass.), Prefix Press and MIT Press, 2008. 
I went to see it pretty much every day. People used it as a toilet, but they also used it for other purposes; it is unusual to have a room that you can lock on the street. There are nice pictures of people smoking inside it. The amber of the cigarette glows through the glass in some pictures. For me there was something utopian in how people could appropriate the space.

This utopian dimension is omnipresent in your work. Model for a Public Space, for example, points straightforwardly to an earlier utopian proposition: Vladimir Tatlin's Monument for the Third International. But here the utopian aspects are so prominent that they might make the work shift into discourse rather than art or architecture.

Yes, there is a very clear reference to Tatlin. Another aspect of that piece is the notion of model, in the sense of an architectural maquette. It is projective and it relies on contingent tectonics. All the variations of Model for a Public Space have been structured using scaffolding. Scaffold is not a permanent structure; you can rent it and then you put it up. When it's over you take it down and send it back. You don't have to own it.

It literally creates a space that is not hierarchical, but it also suggests that this non-hierarchical space is contingent in itself. It might be necessary that it remains contingent for it to allow democratic uses. I'm sympathetic to arguments about democracy like those advanced by Jacques Rancière. He is interested in moments when people stand up and perform politics.

Richard Florida is now your colleague at the University of Toronto, and he is also interested in the role of artists and the "creative class" in the transformation of urban spaces. In The Rise of the Creative Class', he argues that attracting and retaining cultural producers is the primary condition for developing a city's resources for long-term prosperity. In works like Evicted May 1, 2000 (9 Hanna Avenue), however, you seem to be drawing very different conclusions.

My own interest in artists and gentrification is to think about the solidarity artists have with the community. I think of artists as agents who make choices about their residences, about the spaces of the city they inhabit. I made Evicted

2. Richard Florida, The Rise of the Creative Class: And how it's Transforming Work, Leisure, Community and Everyday Life, New York, Basic Books, 2002. 
May 1, 2000 about artists who got displaced from studios at 9 Hanna Avenue, not very far from Queen street. This zone has been completely redeveloped.

Evicted May 1, 2000 used pinhole photographs to illustrate the transformative potential of artists' studio spaces. In these, I was first interested in the openness offered by generic spaces. Then I was fascinated by the various ways in which people inhabit them. There is also something particular in the relationship between the studio space and the structure of the work, which is a generic pin-hole camera, a box, built to match the box-like architecture. So the camera is a model for a series of generic spaces. The image registers the differences between these rooms.

Your art is so strongly rooted in urban politics that I was surprised to learn you presented a work at the International Garden Festival at Les Jardins de Métis in Gaspésie last summer. Was this a respite from your own practice or were you attempting new ways to address issues that are at the core of your work?

That's a good question. The simple answer is that I'm really interested in making things. We talked earlier about this tension between the publicness of art and the autonomy of the creative process. This is what this piece brought back for me. I made it with Jane Hutton, a landscape architect who is very invested in the relationship between ecology and social use. Together we made a garden called Dymaxion Sleep. The structure is an icosahedron made of steel triangles, with nets spread across the triangles. The structure is suspended over an aromatic garden of mint, eucalyptus, lemon geranium and lavender that grows up under the nets. People can lie down suspended over the garden. As they lie, they are at the center of a connection prompted by gravity, which depresses the nets, and the growth of plants. There is rubbing between the two. That - and people touching the leaves - is what releases the smell from the plants. There are a lot of theoretical ideas that are brought together here in terms of an artwork, an architecture that is very occupyable but which also creates an unusual relationship between people who are not necessarily expecting to lie down together. It's very playful, very ludic.

For an architect it's interesting to test such a structure.

Absolutely. This goes back to the beginning of our discussion. There are things that can happen in art that can't be done in architecture. Working on Dymaxion Sleep made me think about how conservative and restrictive building 
codes and legislation are. Dymaxion Sleep is totally not up to code. It's a very interesting structure because it couldn't have been built in other places. It's a kind of hypothetical or utopian structure in that sense too. It's a very rewarding experiment. 